\title{
El Centenario de un Americano Ilustre
}

Iversas publicaciones de Hispanoamérica, nos traen los ecos de
los homenajes tributados a don Federico Henríquez y Carvajal al cumplir los cien años de su vida fecunda. El Congreso Municipal reunido en La Habana y la Conferencia de Estados Americanos en Bogotá, acordaron sendos homenajes al patricio que ha realizado en su vida actos heroicos y ha dejado a las letras un legado que honra a su patria, Santo Domingo. El día 16 de septiembre de 1848 nacía en la Primada de América, Santo Domingo, don Federico Henríquez y Carvajal, rama de una familia que ha dado a la pequeña República ilustres hombres de letras y políticos de acrisolado patriotismo. Hizo sus estudios en el Seminario bajo la dirección de otro prócer dominicano, el padre Fernando Arturo de Meriño. Muy joven se hizo periodista dirigiendo La opinión, órgano del grupo "Juventud". Sucesivamente fué director de Letras y ciencias y de Ateneo. Pasados los ochenta dirigía aún la revista Cho, órgano de la Academia de la Historia dominicana. Ejerció, asimismo, el magisterio, no sólo en la cátedra, sino con el ejemplo de una vida intachable. Enseñó literatura y derecho y ocupó la rectoría de la Universidad.

Uno de sus panegiristas ha dicho que "don Federico hizo suya la causa cubana y compartió las angustias de Martí, López y Maceo. Vió coronadas sus aspiraciones cuando Cuba fué libre. Hoy, entre los papeles del maestro pueden verse tres pliegos en que lo declaran hijo adoptivo de Bayamo, de Santiago de Cuba y de Manzanillo." Con Martí tuvo amistad entrañable. 
Además, actuó sagazmente en las cuestiones internacionales que han interesado a su país. En 1901, vino a México como delegado a la Segunda Conferencia Panamericana. Desde entonces guardó por nuestro país un recuerdo imborrable. México estaba siempre presente en el espíritu de este anciano ilustre. En el año de 1921, en compañía de su sobrino Max Henríquez Ureña, emprendió una peregrinación a través del Continente americano para lograr ayuda que contribuyera a la defensa de su país invadido por fuerzas extrañas. En la prensa y en la tribuna, la voz de don Federico se levantó en pro de los derechos inalienables de América a ser libre. Fué entonces cuando lo conocí. Volviendo atrás la mirada, lo veo en el vestíbulo del Parque Hotel de Montevideo, pequeño y frágil, elocuente y expresivo, hablando de la causa que defendía, recordando a los amigos que tenía en México, juzgando a los autores mexicanos de su generación, informándose de la marcha de nuestra politica, de nuestra historia y de nuestras letras. Agil la mente, fácil la expresión, nada le era extraño de lo que a Hispanoamérica se refería. Perteneció a ese grupo de grandes escritores que a fines del siglo XIX incorporó a nuestro Continente en la historia de la literatura universal. Ya para esa época, había publicado sus libros Páginas selectas, El Derecho Público Internacional y la guerra, Todo por Cuba, Nacionalismo, Del amor y del dolor, Etica y estética, Romances históricos, Duarte, Ramón Mella, Marti. Como todos los ensayistas de su generación, le preocupó siempre el problema de las relaciones entre nuestras dos Américas y trató de resolverlo siempre con valor y con lealtad.

Al rendirle homenaje, la Novena Conferencia Internacional Americana declaró que su "vida ha tenido por dedicación suprema un esfuerzo continuado no sólo para la consolidación de la libertad de su pueblo, sino de todos los hombres de América; que en la parábola de esa vida singular, expresiva de las más altas jerarquías del hombre americano, sus preocupaciones libertadoras lo llevaron a una dedicación fecunda en los esfuerzos necesarios para lograr el nacimiento de la República de Cuba; que don Federico Henríquez y Carvajal extendió su mano a José Martí, en todo el proceso de la organización revolucionaria que llevó a efecto el Libertador cubano en el último episodio del continuado y dramático esfuerzo de los cubanos para lograr su independencia y que don Federico era 
de aquellos hombres escasos como los montes, que saben mirar desde ellos y sienten con entraña de nación o de humanidad".

Al cumplir sus cien años, el maestro dirigió un mensaje a la América en el que decía: "Así, mirando a toda la América libre de dominación extraña, disfrutando cada pueblo de absoluta soberanía e independencia, afianzada en lo interno de la paz jurídica, dentro del ejercicio de todas las libertades ciudadanas, con absoluto respeto de la dignidad del hombre, resolviendo todos sus problemas sociales, armónicamente, sin las perturbaciones de la tiranía, ni de la anarquía, desearía terminar el largo proceso de mi vida, tranquila la conciencia, con amor para todos mis semejantes y con un voto de gracias para cuantos me colman no de ahora, de respeto y de distinciones."

Hace tres años en una rápida visita a la ciudad en que residía el maestro lo vi una vez más. Su cabello había encanecido totalmente, formando un halo de blancura en torno a su faz demacrada como la de un asceta. La luz de sus ojos había desaparecido para siempre; pero conservaba aún la claridad de su juicio y la serenidad de su expresión. Hicimos recuerdos de la primera entrevista y el ilustre viejo volvió a interesarse por la vida intelectual de México y de la América toda.

Nada más justo que el homenaje que se le ha tributado.

JuLio JiMÉnez RUEdA 
